\title{
Contractual Responsibility for the Disclosure of Bank Secrets
}

Alexander V. Syatchikhin

Perm State University, saw065@mail.ru

Valery G. Golubtsov

Perm State University, v.golybtcov@gmail.com

Natalia V. Syropiatova

Perm State University, syropiatova@yandex.ru

Follow this and additional works at: https://commons.erau.edu/jdfsl

Part of the Business Organizations Law Commons, and the Civil Law Commons

\section{Recommended Citation}

Syatchikhin, Alexander V.; Golubtsov, Valery G.; and Syropiatova, Natalia V. (2017) "Contractual

Responsibility for the Disclosure of Bank Secrets," Journal of Digital Forensics, Security and Law. Vol. 12 :

No. 3 , Article 7.

DOI: https://doi.org/10.15394/jdfsl.2017.1454

Available at: https://commons.erau.edu/jdfsl/vol12/iss3/7

This Article is brought to you for free and open access by

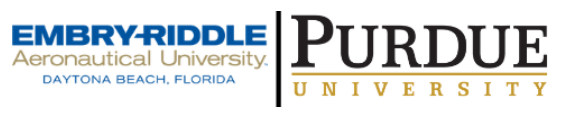
the Journals at Scholarly Commons. It has been accepted for inclusion in Journal of Digital Forensics, Security and Law by an authorized administrator of Scholarly Commons. For more information, please contact commons@erau.edu.

(c)ADFSL 


\title{
CONTRACTUAL RESPONSIBILITY FOR THE DISCLOSURE OF BANK SECRETS
}

\author{
Golubtsov Valery Gennadievich \\ Head of the Department of Entrepreneurship Law, Civil Litigation and Arbitration, Doctor of \\ law, Professor (Perm State University) \\ E-mail:v.golybtcov@gmail.com \\ Syropiatova Natalia Vladimirovna \\ Senior lecturer of the Department of Entrepreneurship Law, Civil Litigation and Arbitration \\ (Perm State University) \\ E-mail: syropiatova@yandex.ru \\ Syatchikhin Alexander Valentinovich \\ Assistant Professor of the Department of Entrepreneurship Law, Civil Litigation and \\ Arbitration (Perm State University) \\ E-mail:doka065@gmail.com
}

\begin{abstract}
In Russia, the existing measures of civil liability for disclosure of bank secrecy contribute to the prevention of non-fulfillment of obligations and the restoration of the situation of credit institutions only to a small extent. Thus, the Civil Code of the Russian Federation grants the creditor the right to recover damages. However, it is practically impossible to prove the size of the real damage and loss of profit, as well as the causal relationship between the disclosure of secrecy and losses in fact. The authors discuss the issue of the possibility of introducing legal design of liquidated damages into domestic civil law, which, in their opinion, can minimize the risk of disclosure of information constituting bank secrecy. This is confirmed by the successful experience of applying the design abroad. The article contains an assessment of the possibility of applying liquidated damages to ensure the safety of banking organizations in modern Russian conditions.
\end{abstract}

Keywords: contractual liability, liquidated damages, incentives for proper performance of obligations, bank secrecy

\section{INTRODUCTION}

In accordance with Part. 1, Art. 23 of the Constitution of the Russian Federation, everyone has the right to inviolability of private life, personal and family secrets, protection of

${ }^{1}$ Constitution of the Russian Federation. Retrieved on December 12, 1993 // Rossijskaja Gazeta, 1993. № 237.

(C) 2017 ADFSL his honor and good name ${ }^{1}$. Specifying these provisions, Art. 26 of the Federal Law "On Banks and Banking Activities" establishes the bank's obligation to keep secret about the transactions, accounts and deposits of their customers, if this does not contradict the federal 
law $^{2}$. In addition, in paragraph 7 of Art. 2 of the Federal Law "On Information, Information Technologies and Information Protection," the legislator establishes a regime of confidentiality of information with respect to information constituting bank secrecy ${ }^{3}$. At the same time, confidentiality means the duty of a person who has access to information not to pass such information to the third parties without the consent of their owner. Compliance with the latter is provided by various public-law and private-law mechanisms - usually through the application of legal liability measures for breach of banking secrecy.

On the one hand, confidentiality of bank secrecy is provided by a number of organizational and technical measures, as it is enshrined, in particular, in the regulatory acts of the Bank of Russia ${ }^{4}$, and, on the other, prohibitive measures of a public-law nature are established by a number of legislative acts. Among them are the Civil Code of the Russian

\footnotetext{
${ }^{2}$ Federal Law "About Banks and Banking Activities». Retrieved on December 2, 1990 // RLB "ConsultantPlus".

${ }^{3}$ Federal Law "On Information, Information Technologies and Information Protection". Retrieved on July 7, 2006 // RLB "ConsultantPlus".

${ }^{4}$ Standard of the Bank of Russia: "Providing information security of organizations of the banking system of the Russian Federation. Collection and analysis of technical data in response to incidents of information security in money transfers" (STO BR IBBS-1.3-2016); Standard of the Bank of Russia: "Providing information security of organizations of the banking system of the Russian Federation. General provisions" (SRT BR IBBS-1.0-2014); Standard of the Bank of Russia: "Providing information security of organizations of the banking system of the Russian Federation. Methodology for assessing the compliance of information security of organizations of the banking system of the Russian Federation with the requirements of the SRT BR IBBS-1.0 - 2014" (SRT BR IBBS-1.2-2014); Standard of the Bank of Russia: "Providing information security of organizations of the banking system of the Russian Federation. Information security audit of SRT BR IBBS-1.1-2007" (SRT BR
}

Federation", the Federal Law "On Banks and Banking Activities," 6 the Federal Law "On Customs Regulation in the Russian Federation," 7 the Customs Code of the Customs Union $^{8}$, the Federal Law "On Credit Histories"9 and the Federal Law "On Currency Regulation and Currency Control;" ${ }^{10}$ however, the above normative legal acts do not provide parties with a flexible legal mechanism for securing bank secrecy, but they usually contain some reference rules on civil, legal, disciplinary, administrative and criminal liability for violation of the confidentiality of information.

At the same time, the effectiveness of public legal measures of civil liability (first of all, compensation of losses) seems to be extremely low, which is connected with the general approach to the application of this sanction. So, to bring a person to justice, it is necessary, firstly, to prove the fact of disclosure of bank secrecy; secondly, to acknowledge the presence of losses and their size; thirdly, to prove the

IBBS-1.1-2007); Recommendations for standardization of the Bank of Russia "Ensuring Information Security of Organizations of the Banking System of the Russian Federation: Ensuring Information Security with the Use of Virtualization Technology" RS BR IBBS-2.8-2015.

${ }^{5}$ Art. 857 of the Civil Code of the Russian Federation. Retrieved on January 26, 1996 // RLB "ConsultantPlus".

${ }^{6}$ Art. 26 of the Federal Law "On Banks and Banking Activities". Retrieved on December 2, 1990 // RLB "ConsultantPlus".

${ }^{7}$ Art. 33, 102, 167 of the Federal Law "On Customs Regulation in the Russian Federation". Retrieved on November 27, 2010 // RLB "ConsultantPlus".

${ }^{8}$ Art. 8, 16, 21, 47, 134 and other of the Customs Code of the Customs Union. Retrieved on November 27, 2009 // RLB "ConsultantPlus".

${ }^{9}$ Art. 17 of the Federal Law "On Credit Histories". Retrieved on December 30, 2004 // RLB "ConsultantPlus".

${ }^{10}$ Art. 23 of the Federal Law "On Currency Regulation and Currency Control". Retrieved on December 10, 2003 // RLB "ConsultantPlus". 
causal relationship between the actions of a person and losses; and, fourthly, to prove the guilt of the causer of harm.

If the proof of the first and last element of the composition of a civil offense, as a rule, is not too complex, then confirmation of losses and cause-and-effect relations often causes difficulties and often effectively deprives the injured party of protection. ${ }^{11}$

In this regard, the literature notes the possibility of bringing to civil liability in this category of cases in proving the truncated composition of a civil offense - by foreclosing a penalty, as a measure of liability that does not require proof of the existence of losses and cause-effect relationships. ${ }^{12}$ At the same time, this sanction is not mentioned in the above legislative acts, and therefore, it is necessary to strive every time at the negotiation stage to include appropriate conditions of a private-law (proactive) nature in the agreement. Penalty in this case will be in the form of a fine, since its size will not be connected with any losses.

\section{CONTRACTUAL RESPONSHHITY}

It should be noted that the expansion of the opportunities for the application of measures of contractual responsibility (private law) is an indicator of the development of civil law, based, inter alia, on the recognition of equality of parties to the regulated relations, the autonomy of their will, the primacy of freedom of contract, freedom to establish their rights and obligations in the treaty, inadmissibility of arbitrary interference in private affairs, the need for unimpeded implementation of civil rights, as

11 See., for example: Selivanovskij, I. (2006) Bankovskaja tajna: sostojanie i problem. Buhgalterija i banki. № 9. P. 28-29; Sapozhnikov, N. (2001) Pravovoj rezhim bankovskoj tajny. Zakonnost', № 7. P. 12 .

(C) 2017 ADFSL well as ensuring the restoration of violated rights.

Thus, contractual liability, in the absence of abuse of one's position by one of the parties, allows us to set up a flexible legal mechanism for restoring the position of the creditor, thereby expanding the guarantees of proper performance of obligations.

However, at the same time, the effective application of measures of contractual liability is impossible without a number of conditions. Firstly, the measures of contractual liability developed by the parties should not contradict the peremptory norms of civil legislation. Secondly, this kind of responsibility is aimed at ensuring the interests of professional participants of civil traffic, as a rule, they have sufficient negotiating capabilities. Thirdly, an important condition for contractual liability is the equality of counterparties (not so much the recognition of the legal equality of the parties as their economic independence), which prevents the abuse of position in the harmonization of contractual liability measures. Fourthly, the effectiveness of contractual liability mechanisms depends on the level of contractual discipline and the activity of the parties in negotiating. Fifthly, in the absence of detailed legislative regulation, the effectiveness of a particular measure of contractual liability becomes directly dependent on the "quality" of the legal technique of drafting the contract, detailed regulation of the procedure for the application of contractual sanctions. Thus, the development of contractual forms of responsibility is an indicator of the developed civil turnover and the high level of professionalism of its participants.

${ }^{12}$ See: Sergeev, A.P., Tolstoi, Ju.K. (2000). Civil Law: textbook. Moscow, Russia: Statut. P. 457; Sapozhnikov N. Op. Cit. 


\section{LIQUDATED DAMAGES}

Returning to the specific legal mechanisms of contractual responsibility, it is worth noting that in domestic practice, forfeit is of the highest "popularity." However, this penalty measure is not fully consistent with the general principle of civil law - the compensatory nature of civil liability measures, which aim not to punish, but to restore the property status of the injured party.

In this regard, it seems advisable to apply in practice the widely known primarily in AngloSaxon law, the design of "liquidated damages." Liquidated damages are a measure of contractual liability, the purpose of which is to restore the position of the creditor to the state in which it was, if the obligation was properly executed (the so-called "positive contractual interest" concept, recently reflected and In the Civil Code of the Russian Federation). The type of loss in question, along with the so-called. "Alternative losses" is one of the methods (techniques) for calculating damages that are of private legal nature, which are determined directly by the parties to the agreement by making a reasonable assessment of the foreseeable losses from violation of specific contract terms.

The considered contractual design is applicable, as a rule, to those cases when it is difficult or even impossible to determine the amount of damage even after the breach of the contract. So, in the context of the disclosure of trade secrets, K. Gorbatov rightly notes that "the problem lies in the need to prove not only the fact of disclosure of commercial secrets, but also that such disclosure has entailed a very specific amount of losses (damage). In practice,

13 Gorbatov K. Kak dorogo obojdetsja razglashenie bankovskoj tajny // Tass, 2015. URL: http://tass.ru/ opinions/1666851. it is almost impossible to calculate the amount of damage to the ruble in such a situation."13 With respect to bank secrecy, the definition of losses presents an even greater difficulty - a person conscientiously performing their duties is eventually put in a situation that is comparatively worse than that of the offender. First, the lender is charged with proving the existence and amount of losses, and secondly, the restoration of his position depends on the evidence of these facts. As a result, the economic "effectiveness of violation" (rather than compliance) of bank secrecy contributes to the growth of offenses in this area. In other words, from an economic point of view, the profit from breaking bank secrecy can repeatedly exceed those adverse consequences that the bankrupt infringer will suffer in the case when the composition of a civil offense is proved.

The lack of effective and efficient ways to protect the creditor leads to a state of legal insecurity of certain categories of participants in civil circulation. The use of the contractual instruments, we believe, is one of the ways to solve this problem. Returning to the contractual design of the previously estimated damages, it should be noted that in order to recover the latter, it is necessary to prove the maximum truncated part of the offense: the fact of disclosure of information constituting bank secrecy and, if there is a dispute regarding the agreed compensation amount, the reasonableness of the assessment of foreseeable losses at the conclusion of the agreement.

It should be noted that the necessity of proving a truncated composition in recovering the amounts of the previously estimated losses, as well as the reasonableness of estimating losses from improper performance of a particular condition of the contract, are not accidental. As 
you know, in countries of common law, where the design of previously estimated losses is actively used, another concept of civil liability in the sphere of legal relations is used - the concept of foreseeability. Its application in practice facilitates the procedure of proof and compensation of damages, since there is no need to prove a causal relationship between the violation of the obligation and the losses. It is enough for the parties to prove the fact of the default and the fact that the losses were foreseen and reasonably estimated.

In addition, it is necessary to pay special attention to the fact that the basis for collecting previously assessed damages is the violation of a specific contractual condition by disclosure of information constituting bank secrecy. Since the law does not specify how to disclose such information, in order to curb possible disputes, the contract should detail the grounds for collecting liquidated damages. Thus, the disclosure of information is considered to be not authorized by the owner of information transfer of information in any way to an unauthorized person (disposition of information contrary to the will of their owner). Among the methods of disclosure, in addition to oral and written ones, in order to facilitate the collection of evidence of disclosure of the above information, the use of mass media, as well as social networks by employees of banking organizations, should be additionally indicated. Moreover, it is necessary to stipulate cases of disclosure through inaction of authorized persons (in case when such inaction violates the confidentiality of information). In this case, inactivity in these cases should not be reduced to a simple passivity of the obligated person, but to be expressed in non-fulfillment of actions prescribed by law or by the contract aimed at preserving bank secrecy.

In addition, it is advisable to indicate information about what cases are not the disclosure of banking secrets by virtue of the law, and, as a consequence, are not grounds for recovering previously estimated losses. This applies, for example, to the assignment of claims arising from a loan agreement (the transfer to the assignee of the obligation to store information that is known to be bank secrecy), the transfer of information about transactions, accounts and deposits of legal entities and individual entrepreneurs to the Federal Financial Monitoring Service Rosfinmonitoring) in order to counteract the legalization or laundering of criminal proceeds, the financing of terrorism, coordination with other executive authorities, etc.

We emphasize that the agreed amount of compensation should constitute a reasonable estimate of foreseeable losses, pursue the goal of restoring the property position of the parties. In this case, the previously estimated losses will be presented as one of the types of losses (methods of calculating them) that do not contradict civil legislation in particular and the public legal order of the Russian Federation as a whole.

\section{CONCLUSION}

We assume that development of the same contractual mechanisms, will allow to build a tool for effective legal regulation of economic relations, to increase contractual discipline, which, in the end, will have a favorable effect on the development of Russian civil turnover and economy. 


\section{REFERENCES}

Civil Code of the Russian Federation. Retrieved on January 26, $1996 \quad / / \quad$ RLB "ConsultantPlus".

Constitution of the Russian Federation. Retrieved on December 12, 1993 // Rossijskaja Gazeta, 1993. № 237.

Customs Code of the Customs Union. Retrieved on November 27, $2009 / / \quad$ RLB "ConsultantPlus".

Federal Law "About Banks and Banking Activities». Retrieved on December 2, 1990 // RLB "ConsultantPlus".

Federal Law "On Banks and Banking Activities". Retrieved on December 2, 1990 // RLB "ConsultantPlus".

Federal Law "On Credit Histories". Retrieved on December 30, 2004 // RLB "ConsultantPlus".

Federal Law "On Currency Regulation and Currency Control". Retrieved on December 10. 2003 // RLB "ConsultantPlus".

Federal Law "On Customs Regulation in the Russian Federation". Retrieved on November 27, 2010 // RLB "ConsultantPlus".

Federal Law "On Information, Information Technologies and Information Protection". Retrieved on July 7, 2006 // RLB "ConsultantPlus".

Gorbatov, K. (2015) Kak dorogo obojdetsja razglashenie bankovskoj tajny. Tass. URL: http:/tass.ru/ opinions/1666851 (Date Accessed: 09.08.2017).

Sergeev, A.P., Tolstoi, Ju.K. (2000). Civil Law: textbook. Moscow, Russia: Statut. Recommendations for standardization of the
Bank of Russia "Ensuring Information Security of Organizations of the Banking System of the Russian Federation: Ensuring Information Security with the Use of Virtualization Technology" RS BR IBBS2.8-2015.

Sapozhnikov, N. (2001) Pravovoj rezhim bankovskoj tajny. Zakonnost', № 7 .

Selivanovskij, I. (2006) Bankovskaja tajna: sostojanie i problem. Buhgalterija i banki. № 9 .

Standard of the Bank of Russia: "Providing information security of organizations of the banking system of the Russian Federation. Collection and analysis of technical data in response to incidents of information security in money transfers" (STO BR IBBS-1.32016).

Standard of the Bank of Russia: "Providing information security of organizations of the banking system of the Russian Federation. General provisions" (SRT BR IBBS-1.02014).

Standard of the Bank of Russia: "Providing information security of organizations of the banking system of the Russian Federation. Methodology for assessing the compliance of information security of organizations of the banking system of the Russian Federation with the requirements of the SRT BR IBBS1.0 - 2014" (SRT BR IBBS-1.2-2014).

Standard of the Bank of Russia: "Providing information security of organizations of the banking system of the Russian Federation. Information security audit of SRT BR. IBBS-1.1-2007" (SRT BR IBBS-1,1-2007). 